\title{
POLITICAL AND ECONOMIC DEVELOPMENT IN CHINA AND RUSSIA DURING THE COLD WAR
}

\author{
Samra Sarfraz Khan ${ }^{*}$
}

\begin{abstract}
The research paper entitled "Political and Economic Development in China and Russia During the Cold War," focuses on the struggles made by the Chinese and Russian governments during the Cold War years for the improvement of economic situation of the two countries. By addressing such questions as the viability of the economic policies of Russia and China, the paper aims to bring to light the various methods used by the two governments to ensure improvement of the economic condition of the state, as well as of its people. Effort has also been made to draw a critical analysis of the power struggles and confrontations within the two regimes and the influence of the same on the political and economic graph of the two states. The paper, therefore, discusses the political issues within the People's Republic of China and Russia and the effects of these frictions on the overall political and economic condition of the country. Moreover, the paper is also an attempt to analyze the reasons why Chinese attempts at economic development were more fruitful than the efforts made by their Russian counterparts.
\end{abstract}

Keywords: Privatization, agricultural, industrial, development, socialist, reforms, government, socialism

\section{Introduction}

Following the victory of the Chinese Communist Party in 1949, China saw an epoch of domestic cultural reforms under Mao Zedong, the then chairman of the Chinese Communist Party (CCP). The new government in China modeled itself on Soviet grounds. From the very onset, the government was confronted with multiple tasks. Among other things, an important issue for the new government was the filtration of party members which had increased speedily from 1,210,000 to 5,000,000 within five years from 1945 to 1950 . As time was not ripe to sieve individuals with counterrevolutionary tendencies from the party and eventually from the country in 1945, the job had to be done in the post-civil war era. For this reason, since its inception in 1949, the newly formed government of the People's Republic of China (PRC) set on the track of domestic reforms. A major step in this regard was the censorship of press in an

\footnotetext{
* Samra Sarfraz Khan, Lecturer, Department of History, University of Karachi
} 
attempt to block the propagation of anti-communist ideas in the country. ${ }^{1}$ Henceforth, media was regulated in a way that could best serve the party's goals. ${ }^{2}$

On the economic front, the government dedicated itself to land reforms and industrialization as jobs and food had to be provided to thousands of poor Chinese simultaneously while the government tried to drag China out of the misery brought about by years of war and revolution. While the traditional occupation of China has been agriculture oriented, the scarcity of enough arable land made it difficult for the people to find suitable livelihood. Therefore, majority of Chinese population traditionally settled around arable lands, which mostly happen to lie on the coastal areas. However, due to the scarcity of suitable land most of the peasants owned too little a land, or in some cases, none at all. These states of affairs had provided impetus that gave fame to Mao's Communist ideas in the decades of 1930s and 1940s, which aimed at solving these problems in the best interests of the peasants and the national economy. ${ }^{3}$

In addition to the wreckage brought by years of war, China also lacked the basic ingredients of modern industrialization; an educated and proficient middle class, competent technology and sufficient capital. Shortly after coming to power in $1949,{ }^{4}$ the government introduced the Agrarian Reform Law with the aim to protect peasant economy and to reset agricultural production. Lands were taken from landlords and were distributed among poor farmers. The government however, reserved the right to reverse the law when the state of affairs became ready for collectivization. ${ }^{5}$ Although the redistribution of land cost many lives, by 1953, however, "major industries were nationalized, foreign enterprises were confiscated, and private enterprise was eliminated gradually as state control of the economy was increased." ${ }^{\prime 6}$

In the same year, that is, in 1953, guided by economic experts from the Soviet Union, Mao considered China ready to introduce the First Five Year Plan (1953-57). With significant technical assistance from the USSR, the First Five Year Plan achieved its goal of rapid heavy industrial development with noteworthy growth in electricity, steel and cement production of China. ${ }^{7}$ The First Five Year Plan is also significant for the changes it introduced in the previous techniques of Chinese economic management. For example, in contrast to the war-time local management, economic planning was, from now on, to

\footnotetext{
${ }^{1}$. Most of the films produced during the early years of CCP's government were restricted to documentaries and features advocating communist ideas. Schools and colleges were also oriented on a pro-Marxist pattern to further stamp the establishment of Marxist culture in the country.

2. Nathaniel Peffer, The Far East: A Modern History,(Michigan: University of Michigan Press, 1968), p.452453

3. Wayne C. McWilliams, Harry Piotrowski, The World Since 1945: A History of International Relations,(New Delhi: Viva Books, 2006), p.353

${ }^{4}$. Ibid, p. 354

5. Nathaniel Peffer, The Far East: A Modern History, Op.cit., p. 453

${ }^{6}$. Wayne C. McWilliams, Harry Piotrowski, The World Since 1945: A History of International Relations, Op.Cit., p.354

7. Ibid, p.354
} 
be highly "vertical" or centralized; under the control of government ministries, while the "horizontal" role of regional or provincial authorities was reduced next to nothing. ${ }^{8}$

\section{Research Questions}

- Why was Mao Zadong's unable to achieve the goals of socio-economic development in China to their full context?

- What differences under Deng Xiaoping's administration helped in achieving an economically developed China?

- What were the methods applied by USSR for the development of its socioeconomic sector?

- Why was Russia unable to develop it's economy during the Cold War years, while China following Soviet model was successful?

\section{Literature Review}

Although the First Five Year Plan made good impact on Chinese society, it was not without its drawbacks. For instance, largely ignoring the agricultural sector, the Plan focused mainly on the development of heavy industry. A major influx of capital for this Plan was to be generated from the state and the rest from the Soviet Union which invested in 156 major projects, but mostly in the form of short-term loans. Therefore, most of the costs had to be paid by Chinese people, of whom majority were peasants. To overcome this problem, in 1952, the Chinese government fixed the agricultural tax for every household, by which the amount of tax declined in relation with increased production. Thus, the moderate burden on the rural sector, along with the development of heavy industrial sector resulted in improved standards of living during the First Five Year Plan. ${ }^{9}$ The industrial growth of 15.5 percent per year, the rapid increase in heavy industry production was simultaneous with a prominent decrease in agricultural production and a sharp increase in China's urban population which created a burden on food supplies. ${ }^{10}$

As regards the land reforms during the First Five Year Plan, the process was completed with relative ease as compared to the situation during the same process in the Soviet Union following the early years of the Bolshevik Revolution. Poor harvests during 1953 and 1954 were followed by the collectivization of Chinese farms. By 1956, a major bulk of Chinese farmers, approximately 90 percent, had joined collective farms. ${ }^{11}$

In the year 1957, the Second Five Year Plan was launched to address both industrial as well as agricultural issues. But due to the fear of the creation of powerful bureaucratic

\footnotetext{
${ }^{8}$. Marc J. Blecher, China against the Tides: Restructuring through Revolution, Radicalism, and Reform, (New York: Continuum Publishing Group Inc, 2010), p.35.

${ }^{9}$. Marc J. Blecher, China against the Tides: Restructuring through Revolution, Radicalism, and Reform, Op.cit., p.36

${ }^{10}$. Ibid, p. 37

${ }^{11}$. http://www.fsmitha.com/h2/ch25prc.html
} 
elite as in the Soviet Union, Mao suddenly called a halt to the Second Five Year Plan in 1958. In its place, Mao launched the Great Leap Forward, aimed at addressing agricultural growth besides focusing on the development of light industry rather than heavy industry as in the First Five Year Plan. The Great Leap was directed at utilizing China's greatest resource; its people, who were to be given the chance to "industrialize and collectivize" under the proposed plan. The collective farms of the 1950s were reshaped into large communes, designed to serve the foremost Marxist principle; "from each according to his abilities, to each according to his needs". ${ }^{12}$ Through this plan, Mao wanted to move faster towards the Communist Utopia spoken of by Karl Marx. He believed that China had more than just one reason to achieve the Communist goal before the Soviet Union. This notion of Mao is best presented in his writing of 1955:

\begin{abstract}
If we compare our government with the Soviet Union: (1) we had twenty years' experience in the base areas, and were trained in three revolutionary wars; our experience (on coming to power) was exceedingly rich... Therefore, we were able to set up a state very quickly, and complete the tasks of the revolution. (The Soviet Union was a newly established state; at the time of the October Revolution, they had neither army nor government apparatus and they were very few party members.) (2) We enjoy the assistance of the Soviet Union and other democratic countries. (3) Our population is very numerous, and our position is excellent. [Our People] work industriously and bear much hardship, and there is no way for the peasants without co-operativization. Chinese peasants are even better than the English and American workers. Consequently, we can reach socialism more, better, and faster. ${ }^{13}$
\end{abstract}

From here, it is easy to discern two different strategies working in Communist China; Maoist or radical, and moderate. The radical or Maoist approach stressed upon the power of the people, and ideological devotion. On the other hand, moderate approach stressed upon state planning, bureaucratic leadership, and the development of skills and expertise necessary for the development of China. During the first half of 1960s, moderates had taken charge of correcting the mistakes of the Great Leap Forward. Under such leaders as Liu Shaoqi and Deng Xiaoping the economy considerably recovered. Mao was disturbed by the trend towards bureaucracy and in July 1966, he initiated the Great Proletarian Cultural Revolution with the determination to curtail bureaucracy. He accused the moderates of distorting Marxist theory. He enrolled the youth, who had been dismissed from schools, as Red Guards and made them responsible for convincing people for reform all across China through the study of the Little Red Book. The Cultural Revolution was unique in that it was a revolution within an already functioning revolution. Many call this revolution as an attempt at creating a Utopian egalitarian society free from all sorts of class exploitation.

It took almost a decade for the effects of the Cultural Revolution to fade down. By the early 1970s, against Mao's illness, the Cultural Revolution was already beginning to slow down. During these years, leadership of the party went in the hands of Zhou Enlai. Zhou

12. Wayne C. McWilliams, Harry Piotrowski, The World Since 1945: A History of International Relations, Op.cit., p.354

${ }^{13}$. Denis Crispin Twitchett, John King, The Cambridge History of China: The People's Republic, Revolutions within the Chinese Revolution: 1966-1982, (Cambridge: University of Cambridge Press, 1991), p.20 
depended on moderates for bringing China back on the track for economic development. During his term in office, the tension between Radicals and Moderates did not surface. But following the death of Mao Zedong and Premier Zhou Enlai in1976 these tensions surfaced again. Mao's chosen successor was Hua Guofeng, who, together with the moderate leader, Deng Xiaoping was able to curb radicalism in Chinese politics and society. However, Hua's basic ideology, as it is often called the 'two whatever principles aimed at "whatever policy Chairman Mao decided upon, we shall resolutely defend; whatever directives Chairman Mao issued, we shall steadfastly obey ${ }^{14}$ were against his actions and motives. He was not as staunch a follower of Mao as his 'two whatevers' motto suggests. He primarily aimed at a rapid economic growth under a 1950s style of highly centralized planning, together with an attempt at Mao's goal of ending class struggle. Besides, in contrast to Mao, Hua Guofeng also lacked blind trust of the Chinese people. Moreover, the Chinese, especially the youth, by this time were already tired of political and economic adventurism. Xidan Street in Beijing, at a short distance from the famous Tiananmen Square became the center of political opposition display by the Chinese youth. They blamed the CCP for acting more like a dictatorship and called upon the need for an acceptable solution. For many of the protestors, the solution to China's problems laid in democracy, which meant to them openness, freedom of speech and tolerance. In view of these activities, Xidan Street became famous as the Democracy Wall. Democracy, in fact was the fifth pillar, without which it would be impossible for China to achieve the other four modernizations set forward by Zhou Enlai in1963, namely; agriculture, industry, technology and defense. The Democracy Wall Movement (1978-79) coincided with the struggle within the Central Committee of the Communist Party. Hua's efforts could not stop Deng Xiaoping and his supporters in the PLA form contesting for power. ${ }^{15}$

Deng favored the post of Chairman of the Central Military Affairs Commission himself, whereas the seats of Chairman of CCP and the Premiere were to be given to Hu Yaobang and Zhao Ziyang respectively. The two statesmen favored a liberal vigorous economic reform against the cautious policy advocated by the party conservatives such as Deng Liqun. The activists of the Democracy Wall Movement were closely following the tussle between Liqun's ideas and the Liberals' ideas. The activists had been criticizing Hua's government for its dictatorial methods. The repeated criticism had led to enough political chaos in the country by 1979, which in Liqun's opinion; China was not in a position to sustain. According to Deng Liqun, in order to attain the Four Modernizations, China must follow the Four Cardinal Principles of Deng Xiaoping; "upholding the socialist path, upholding the people's democratic dictatorship, upholding the leadership of the CCP, and upholding Marxism-Leninism-Mao Zedong Thought."

Deng Xiaoping had understood the need to avert people's orthodox approach towards Mao's policy and ideology. Liberation of mind from Maoist ideology was indeed necessary if the country had to have access to science, technology and modernization. Mao's ideology was also being effectively used by Hua to justify his party leadership.

${ }^{14}$. Harold Miles Tanner, China: A History,(Indiana: Hacket Publishing Inc., 2009), p.543

15. Ibid, pp.544-545

${ }^{16}$. Ibid, p.546 
Therefore, in 1981, Deng and the party approved a document entitled "The Resolution of the Central Committee of the Chinese Communist Party on some Historical problems since 1949". ${ }^{17}$ The Resolution was in fact an assessment of the inner conflicts in the party with a stress on Mao's mistakes during the period from 1956 to 1976. While the Resolution highlighted Mao's leadership qualities before the victory of 1949, the Communist Party victory in 1949, and the success of the First Five Year Plan; it also criticized Mao's classification of many loyalists as "anti-regime rightists" and his use of humiliating means against them. ${ }^{18}$ Moreover, the document also attested Mao's expectation of high agro-industrial output as unjustifiable and impractical. The Resolution further addressed Hua's failures in coming up to people's expectations, and emphasized on the need for Deng Xiaoping to follow Marxism-Leninism-Mao Zedong thought in its true spirit. ${ }^{19}$

By 1981, Deng had undertaken to shift the CCP's attention from class struggle to economic reconstruction. Therefore, the post-Mao era denotes an era of dynamic economic reforms that opened China to the world. The last twenty years of the twentieth century saw China shifting from an agrarian into an economic and industrial power at par with Asian and international giants. During these two decades, Chinese economy grew at approximately 9 percent per year, while the living standards of the Chinese improved four times better from the standard of previous years. China's shift to market economy also meant a considerable deviation of power from the center in favor of the new middle class. $^{20}$

Deng began his reforms from the countryside where 80 percent of the Chinese population lived. Moreover, by the late 1970s, Chinese political elite had also become perceptive to the economic development of their East Asian neighbors, including South Korea, Singapore, and Japan. Consequently, China gradually shifted from Marxist form of development to an East Asian model for development. Deng, therefore, followed the example of China's East Asian neighbors in dealing with the issues of family farms, international trade, market economy, industry and technology. Hence, when peasants in the post-Mao years started taking their family farms out from the collectives, Deng allowed this process of decentralization to continue to the length and breadth of China. As a result, with increased levels of production in the countryside, it became the most dynamic sector of China's economic sphere. ${ }^{21}$ These reforms of Deng were in sharp contrast with Mao's staunch ideological trends for Deng believed, "it doesn't matter what color the cat is, as long as it catches mice". ${ }^{22}$ Deng's policy was of socialism with Chinese characteristics, with the goal to move towards a market economy and into the international sphere while keeping intact the political system of the communist state.

\footnotetext{
${ }^{17}$. David Wen-Wei Chang, China Under Deng Xiaoping: Political and Economic Reform, Op.cit., p.34

${ }^{18}$. Ibid, pp.35-36

${ }^{19}$. Ibid, pp.36-37

${ }^{20}$. John King Fairbank, Merle Goldman, China: A New History, (Massachusetts: Harvard University Press, 2006), p.344

${ }^{21}$. Ibid, p.408

${ }^{22}$. Wayne C. McWilliams, Harry Piotrowski, The World Since 1945: A History of International Relations, Op.cit., p.358
} 
Deng's policy of 'opening' China to the west brought an influx of western ideas by means of literature, telecommunication, tourism and media. The internet and cellular phone revolution of the mid 1990 s, further added to the pouring of western ideas into China. But it was a deliberate act on the part of Deng and his associates that reduced the party's hold on many socio-economic aspects of the country. Moreover, Deng did not shy from using the positive elements of Mao's era for a further elevation of Chinese society. For example, during the Cultural Revolution and the Great Leap Forward, communes and local work brigades had been promoted to build small-scale industries for metallurgy, chemicals and fertilizers. During the 1980s, local governments gave low interest loans and imposed lower taxes to stimulate a volatile growth of these small-sized local industries, called the Township and Village Enterprises (TVEs). ${ }^{23}$

By 1989, the economic and rural reforms had brought discernible increases in the agroindustrial production. For example, the grain output in 1986 increased 10 million tons from the level of 1985, thus reaching 390 million tons. Steel, Copper, cement and iron showed a 10 percent increase with in a year's time from 1985 to $1986 .{ }^{24}$ This economic development of the post-Mao years transformed China into a market economy from the status of the previous agriculture based economy.

During the decade of 1990s, a trend towards industrial privatization was quite apparent in China. At an annual growth rate of 20 percent per year, the private sector contributed to more than 60 percent of China's GNP by 2004. According to Barry Naughton, an internationally recognized expert on Chinese economy, the evolution of the "one family, two households system" was the hallmark of this period. With this, one member of the family remained allied with the public sector and in return enjoyed subsidized housing, and education, medical and pension benefits while the spouse entered the new and promising market economy. The result was an increased improvement in the living standards of Chinese citizens. Furthermore, better standards of living brought increased household savings into the banking sector. The consequent increase in national funds gave increased chances for investment, thereby adding to the national economic growth. The Chinese, unlike their Russian counterparts did not embark on an immediate privatization of state industry. This was partly due to ideological grounds of the conservative members of the party and partly on account of the government's forethought of the mass unemployment from state owned industries that would arise as a consequence of rapid privatization. ${ }^{25}$

In the case of Russia, however, though Beijing imitated many of the Soviet policies and branded them Chinese in the doing, there still remain wide similarities as well as healthy contrasts in the policy map of the Chinese and Russians. To understand this, a comprehensive study of development in Russia is given below.

${ }^{23}$. Harold Miles Tanner, China: A History, Op.Cit., p.548

${ }^{24}$. David Wen-Wei Chang, China Under Deng Xiaoping: Political and Economic Reform, Op.Cit., p.258

25. Ibid, p.415 


\section{Politics and economy in Cold-War Russia}

Although the demise of the Soviet Union in 1991 considerably shrank the size of the country, Russia nevertheless remains the largest country in the world. Lying on the Eurasian landmass, it is divided by the Ural Mountains into European and Asiatic Russia. Many scholars of international repute tend to stress upon the Eurasian character of Russia, and believe it to be falling in the Inner Eurasian sphere, which includes the areas of the former Soviet Union, Mongolia, and the Asian territory of China. The European part of Russia extends from the Ural Mountains up to the Enesei River. Siberia is also a part of European Russia. Another important mountainous range of Russia besides Ural is the Caucasus Mountains which lie on Russia's south-western borders, on the south and north of Black Sea and Caspian Sea respectively. Other than mountains, rivers have played an important role, and continue to be an important element in the country's foreign and local affairs. ${ }^{26}$ The Volga and Dnieper along with the Western Dvina River provide connecting channels between the Baltic, Black and the Caspian seas by means of canals and portages. Since the time of Peter the Great, gaining an access into the Black Sea and the Baltic Sea has been a corner stone in Russian foreign policy, which it eventually acquired in the outcome of a series of Russo-Turkish wars. Even after the dissolution of the Soviet Union, Russia still has a coastal line along these seas. ${ }^{27}$

Among other factors, the geography of Russia has provided the stimulus for colonization and expansion. Besides, the need for fertile lands, access to warm water and the demand for Siberian furs, the presence of "porous frontiers" 28 was also a contributing factor in Russian expansion. Porous frontiers were also the reason for Russia's profound emphasis on its military throughout the course of its history. As a result, various Russian leaders expanded their natural borders, as a consequence of which, many non-Russian populace were absorbed into the Russian Empire, thus making it a multinational state. It was this mixed population of Russia that created problems in its local and foreign affairs and ultimately brought about the fall of the USSR in 1991.

Form a retrospective perspective, the Russian Revolution of 1917 was influenced by such European ideas as Idealism and Enlightenment which had changed the course of European history itself. In 1917, two major revolutions in Russia changed the very track of Russian history. The March Revolution (February Revolution as per the Julian calendar) deposed the Czar and installed a provisional government in its place; the November Revolution (October Revolution according to the Julian calendar), saw the overthrow of this government by the Bolsheviks under the leadership of Vladimir Lenin. The Bolsheviks saw their victory as victory of the proletariat. The Bolsheviks structured their government on close centralized system that was contrary to the contemporary ideas of democracy. After forming a new government in the state of the Union of Soviet Socialist Republics (USSR), the Bolsheviks set about to counter the many tasks confronting the new government. The tasks involved taking control of the far flung

${ }^{26}$. Walter Moss, A History of Russia, Vol 2: Since 1855, (London: Anthem Press, 2005), p.4

${ }^{27}$. Ibid, p.5

28. Ibid, p.7 
countryside, ensuring food supply to the Russian masses, and to manage the industrial sector.

The economic sector formed the key element of Russian home policy at the time. With the death of Lenin in 1924, Joseph Stalin, a firm believer in the need for an industrialized Russia for the attainment of socialist goals, became the next party leader in 1929. In 1929, he ordered the confiscation of the lands of those peasants who were found involved in hoarding the produce. In reaction to the consequent opposition from the peasants, Stalin introduced forced collectivization of lands in 1930. This meant an eradication of private ownership in favor of state ownership of the land. The Rightist branch of the party objected to Stalin's policy which they believed would turn the peasant population against the state, lead to an exodus of the bulk of peasant class and thus create a drain of manpower form the country, and would hamper rather than accelerate industrialization. Alleging the Rightists of trying to foster capitalist ideas, Stalin had these elements removed from the party by the end of 1930. Stalin then set on the task of designing and implementing his First Five Year Plan.

The First Five Year Plan (1928-1933) proved to be a disaster in Soviet history. Scores of peasants who resisted against the transfer of their lands and properties were executed. ${ }^{29}$ The introduction of collective farms, with state-supplied machinery and seeds, was an attempt at mobilizing peasants towards industrial labor. As a result, nine million peasants became laborers in industries during the First Five Year Plan. The same period also saw the industrial and urban population being doubled. When Stalin announced a pause in the Plan in view of its unprecedented success or being "dizzy with success", it was actually in face of the huge reduction in Soviet agricultural production. However, the pause was not intended to be permanent. By the end of the First Five Year Plan, approximately, 62 percent of the Russian peasants were engaged in collective farms. The living conditions also significantly declined during the course of the Plan. A large number of peasants had either been killed or exiled to Siberia while other hundreds of thousands had died during the famine of 1932-33. ${ }^{30}$ During the Second Five Year Plan (1933-1937), Stalin somewhat relaxed his struggle against bourgeoisie and allowed technocrats to again enter into the factories. ${ }^{31}$

Things started changing for USSR following the death of Stalin in 1953 when he was succeeded by Nikita Khrushchev, who centered his policy on 'de-Stalinization'. His disregard for terror being used as a state policy resulted in the subordination of KGB (Russian secret police) to party control. He slightly liberalized the media, by allowing the publication of critical works on Stalin. As for the centralized system of government, the method continued without any alterations. Khrushchev was succeeded by Leonid Brezhnev in 1964 who until his death in 1982, worked to reverse the process of deStalinization. It was during this time that it was felt that in order to uphold the super power status; it was necessary to keep up with the global arms race. Therefore, heavy

29. As per estimates, the number of horses and cattle, during 1929 to 1933, declined from 36 million to 15 million and from 67 to 34 million respectively.

${ }^{30}$. John Merriman, A History of Modern Europe, Vol.2 From the French Revolution to the Present, (New York:

W.W Norton \& Co., 1996), pp.1132-1133

${ }^{31}$. Ibid, p. 1134 
investment was made in the military sector to keep up to popular aspirations. In these conditions, when Mikhail Gorbachev took the party leadership in 1985, he hoped to drive the Soviet economy, renew the political structure, without changing the ideological structure of the Communist Party. His reform program focused on four main principles:

- Perestroika(restructuring):decentralization of economic sector to allow efficient and innovative growth in individual enterprises. Centralized planning was not to be completely abolished

- Glasnost (openness): relaxing government control on state media.

- Demokraitizatsiia (democracy as per Gorbachev's ideals): increase government's accountability to the public by allowing limited elections.

- New Thinking: emphasized on USSR's integration in the world economy, stressed on the common challenges of arms race confronting the East and West.

The introduction of these reforms changed the nature of state-public relationship in the USSR. People could now cast their opinions more freely through newly created organizations. By the 1990s, pressure from both within and outside the party forced the government to annul Article 6 of the constitution which legalized single-party rule in the USSR. In addition to this, pressure from nascent political parties led to the first contested elections (since the early twentieth century) in 1989 and 1990. However, the most critical issues confronting Gorbachev remained the demand for autonomy and in some cases even secession from the USSR by the Union Republics. The attempts for making a new federal system failed, so did the economic policies of Gorbachev. ${ }^{32}$

Gorbachev's reforms failed to satisfy both the right and left wing of the party. The Rightist saw his reforms as a distraction of the Soviet state, while the leftists were disappointed over the fact that his reforms were not as far reaching as they ought to have been. Therefore, by the mid of 1990, the right and left wing of the party wanted to get rid of Gorbachev, who along with his economic aides had reached the conclusion that legalizing capitalism was indispensable. In 1990, Gorbachev would have accepted the Shatalin Plan, designed by Stanislav Shatalin that advocated the need for transition from centralization to market economy or capitalism within a period of 500 days. But while Shatalin had presented a sound model for economic reforms, he had not addressed the problems that would arise in the awake of his plan. Gorbachev, fearing the opposition from left wing of the party under Boris Yeltsin, who sought to depose him and dissolve USSR, moved to the rightists. Following Yeltsin's quittance from the party in July 1990, Gorbachev and the conservatives shifted to the leftists to avoid the dissolution of Soviet Union. In 1991, the 9-plus-1 formula was concluded between Gorbachev and Yeltsin which called for a decentralized USSR, whereby, the republics would have virtually autonomous powers in almost every sphere. Only currency, diplomacy, and military were to be handled by the central government.

${ }^{32}$. Mark Kesselman et al. European Politics in Transition, Op.cit., pp.330-332 
In the face of these events, in 1991, Yeltsin won victory in the elections which instituted him as the first popularly elected president of the Russian state. Gorbachev, however, continued to drift towards the leftists. These conditions resulted in a coup d'état by the leaders of the Soviet military and parliament. In December 1991, the red flag of the Bolsheviks with its golden hammer and sickle was rolled down and in its place was hoisted the old flag of imperial Russia. ${ }^{33}$ Boris Yeltsin joined leaders of Ukraine and Belorussia to proclaim the formation of the Commonwealth of Independent States (CIS) in place of the Soviet Union. Yeltsin and the leaders of CIS embraced a disintegrating economy. ${ }^{34}$ He however, introduced market reforms for the ailing Russian economy. In 1992, he reduced price control on most of the products. This, along with the "soft monetary policy' of the Central Bank of Russia, led to high inflation. The consumer price index increased to approximately 2,500 between December 1991 and December 1992. ${ }^{35}$ Yeltsin and his team implied on taking loans from the capitalist nations, but Reagan's "push for military superiority" had already created a "binge of borrowing". Similarly, with the crash of the Japanese stock market and the consequent global recession, the time of low-priced capital were now gone. ${ }^{36}$

\section{Discussion}

By the late 1990s, a recession, severe than the Great Depression of 1930s; had engulfed the Russian state. ${ }^{37}$ In this situation, the government introduced the program of rapid privatization in 1992. By 1994, almost 80 percent of medium and large state enterprises in particular economic sectors were changed into joint-stock industries. Agricultural privatization put an even sorry show than the industrial privatization. The government installed large joint stock companies and the organizations of individual families to replace the former collective farms. These enterprises gave disappointing results, and the agricultural sector faced a serious decline throughout the 1990s. In 1995, under a second phase of privatization, enterprises were allowed to sell their shares. Nevertheless, as many of the Russian firms were financially unappealing to local and foreign investors; not much positive results could be achieved. However, there was an exception in oil, gas, telecommunication, and minerals sector, and they fell in the hands of those industrialists who had close connections in the government. In 1996, when the Russian government launched the loans-for-shares program, it was criticized for actually strengthening Russian business elite by transferring them the control of profitable firms in return for paying loans to the Russian government. However, through this program, the private sector was encouraged to start small businesses. This sector, in return, turned out to become a vibrant one in the long run. But, in comparison to the western experience of small business (cafes, restaurants, etc.) where it contributed around 50 percent in the

\footnotetext{
33. Wayne C. McWilliams, Harry Piotrowski, The World Since 1945: A History of International Relations, Op.Cit., pp.466-467

34. Ibid.

35. Mark Kesselman et al. European Politics in Transition, Op.cit., p.343

${ }^{36}$. Wayne C. et.al, The World Since 1945, Op.cit., p.469

${ }^{37}$. Industrial production was less than half of what it had been in 1990 . Heavy and light industries, construction, and wood craft sector were among the most badly affected quarters of economy. The state found it equally difficult to make arrangements for pension payments and the provision of social benefits.
} 
GNP, in Russia, the sector has only provided a share of 10-15 percent of GNP because of such obstacles as high taxation, and capital shortage.

On the contrary, in the case of China, an important factor in regard to the country's economic growth during the 1980s was the involvement of overseas Chinese whose ancestors had migrated first to Southeast Asia and later on to the USA. Mao had rejected their offer to assist China in its economic program, but Deng, acknowledging the professional experience they had gathered abroad, encouraged them to invest in China. Consequently, an increased participation of foreign, especially Taiwanese businessmen could be seen during the 1990s. Of significant importance in this context was the southeastern coast of China which saw increased economic activity and thus became the most dynamic business hub of Asia during this time. In view of the increased business here, Deng's government initiated a new cycle of reforms in 1988 which mainly addressed the need for reforms in urban areas and for the establishment of large private companies. This phase of reforms also included the Special Economic Zones along the Chinese coast where foreign companies had either set up industries or were working jointly with Chinese companies with comparatively less interference from the state. These zones (Shenzhen, Zhuhai, Shantou, Xiamen and the province of Hainan) were important to the Chinese as they provided China with the much sought after capital, technology and innovation and cheap labor.

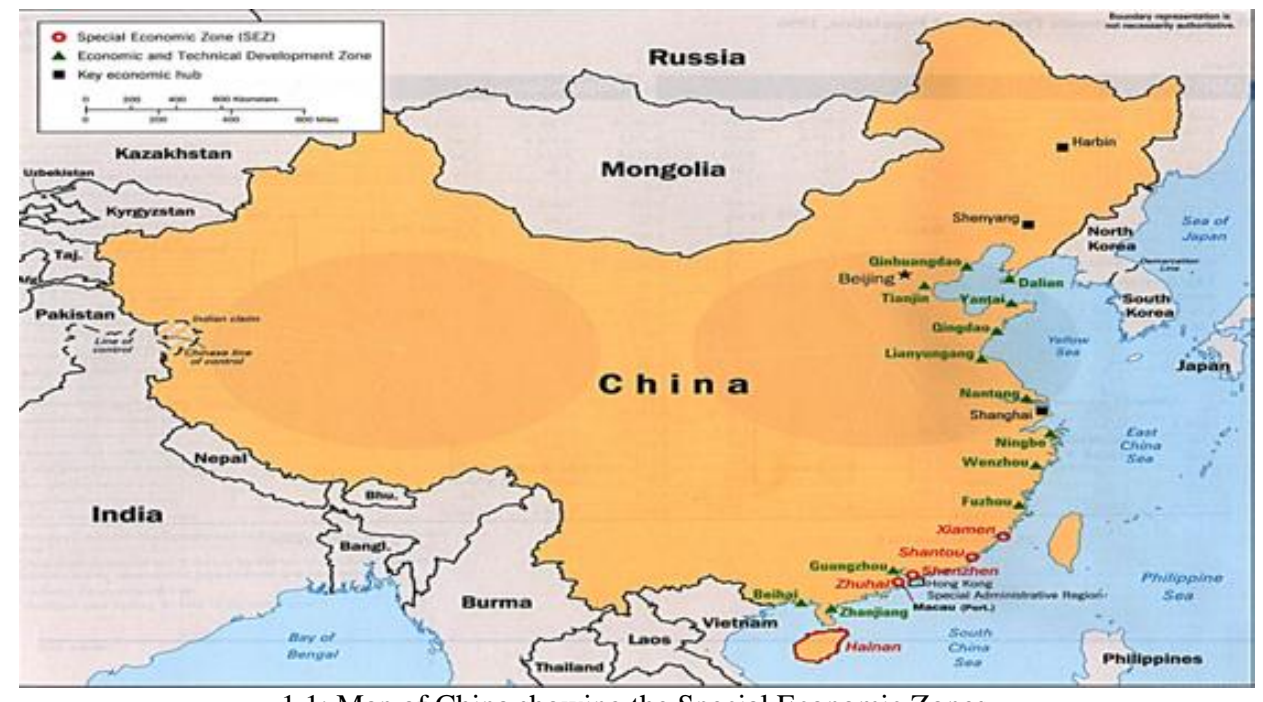

1.1: Map of China showing the Special Economic Zones

Even a sketchy study of the Russian history shows that the problems faced by the Russian government during the Cold War years and in the post-1991 era were multi-dimensional in character. Not only had the Russians to fight an ideological war with Capitalist world, but there were also serious socio-economic and security issues at home that needed to be dealt with. The ever large span of Russian landmass required varying methodologies to 
be implemented in dealing with the even more varying sets of problems in different national sections. One such major task before the Russian government was the simmering ethno-political tensions in the Russian periphery, arising from years of poor economic performance and social inequalities.

\section{Conclusion}

The changes experienced in China were different in practice and application from the Soviet Union. In the USSR changes were brought all together at once, while in China the reforms came at a piecemeal and gradual pace. Moreover, unlike the USSR, where a sudden decline was noticed in the standard of living, employment rate and production; the agricultural and industrial output increased in China, and so did the standard of living for a majority of the Chinese people. The economic success in China is partly an attribute of the short-term existence of Marxist and Leninist system in the country. Russia, on the other hand, had been living under this system for almost seven decades, whereas in China, the system had a shorter history of about thirty years. As a result, many Chinese still remembered the methods of conducting market practices in the post-1949 era. Besides, in China reforms were implemented from bottom to top levels, unlike Russia where changes were first introduced at higher levels. ${ }^{38}$

Moreover, the presence of foreign-based Chinese, along with western and Japanese activities in the region not only accelerated China's economic growth but also gave an impetus in favor of China's move to a market economy and its participation in international trade thereby further reducing the economic control exercised by the CCP. ${ }^{39}$ In short, many obstacles stood in the way of Russia's development into a formidable economy while the turn of events, opportunities and modifications in policy implementation favored the economic growth of China during the Cold-War years.

${ }^{38}$. John King Fairbank, Merle Goldman, China: A New History, Op.Cit., p.411

39. Ibid., p.414 